\title{
O CRITÉRIO PLAUMANN E A (NÃO) COEXISTÊNCIA COM O PRINCÍPIO DA EFETIVA TUTELA JURISDICIONAL ${ }^{1}$
}

\section{THE PLAUMANN TEST AND THE INCOMPATIBILITY WITH THE PRINCIPLE OF EFFECTIVE JUDICIAL PROTECTION}

Paula Ferreira Bovo

Especialista em Direito, Mestre em Direito Processual na Universidade de Coimbra/Portugal. Advogada. Londrina/PR. E-mail: paulabovo@hotmail.com

Patrícia Ayub da Costa Doutoranda em Direito Internacional pela Universidade de São Paulo - FDUSP, Docente do curso de Direito da Universidade Estadual de Londrina, Advogada. Londrina/PR. E-mail: patricia.ayub@uel.br

RESUMO: O instrumento para anular os atos das instituições europeias é o chamado recurso de anulação. Segundo o Tratado de Funcionamento da União Europeia, os particulares, para terem legitimidade, devem demonstrar que são afetados direta e individualmente pelo ato. Essa expressão foi trazida pelo Tratado, mas não foi definida. O Tribunal de Justiça definiu o que entende por afetação direta e individual, tendo-o feito no caso Plaumann. $\mathrm{O}$ trabalho analisa se esse critério de legitimidade posto pelo Tribunal coaduna com o princípio da tutela jurisdicional efetiva, bem como se existem outras alternativas, que cumpram o mesmo papel, à disposição dos particulares.

PALAVRAS-CHAVE: Ação de anulação. Legitimidade. Reenvio prejudicial. Tutela Jurisdicional Efetiva. Particulares.

\footnotetext{
${ }^{1}$ Artigo recebido em 25/08/2020 e aprovado em 26/11/2020.
} 
ABSTRACT: The action for annulment is the judicial remedy used to attack acts edited by the Community institutions. The Treaty on the European Community (EC) says the individuals, to have locus standi conditions, shall demonstrate they are direct and individual affected. The expression direct and individual was written on the Treaty, but it was not explained. The Court of the Justice has defined what it is individual concern, and The Court did this in the Plaumann case. This researches analyses if the Plaumann test coexists with the principle of the effective judicial protection, and if there are other legal alternatives or remedies available to the individuals.

KEY WORDS: Action for annulment. Locus standi. Preliminary References. Effective judicial protection. Individuals.

\section{Considerações iniciais: o princípio da tutela jurisdicional efetiva no âmbito da União}

\section{Europeia}

Com a entrada em vigor do Tratado de Lisboa, a União Europeia passou a atribuir o mesmo valor jurídico dos Tratados à Carta dos Direitos Fundamentais da União Europeia (doravante CDFUE), passando a reconhecer os direitos, as garantias e os princípios ali anunciados $^{2}$. Ainda, passaram a fazer parte do direito da União Europeia, enquanto princípios gerais, os direitos humanos assentados na Convenção Europeia para a Proteção dos Direitos do Homem e das Liberdades Fundamentais e tal como resultam das tradições constitucionais comuns aos Estados-Membros ${ }^{3}$.

Dentre as garantias previstas na CDFUE, estampa-se no art. $47^{\circ} .1$ que "toda a pessoa cujos direitos e liberdades garantidos pelo direito da União tenham sido violados tem direito a uma ação perante um tribunal". Apesar de o texto em português mencionar o direito a uma ação, é importante ressaltar que noutras línguas como, por exemplo, espanhol e inglês, constam as expressões, respectivamente, derecho a la tutela judicial efectiva e rigth to na effective remedy, sendo que se entende que o que expressa o artigo é, em verdade, o direito

\footnotetext{
${ }^{2}$ Art. $6^{\circ} .1$ do Tratado de Lisboa.

${ }^{3}$ Art. $6^{\circ} .3$ do Tratado de Lisboa.
} 
à tutela jurisdicional efetiva, e não ao mero acesso a tribunais ${ }^{4}$. Além da previsão na CDFUE, a fiscalização está na base das tradições constitucionais comuns dos Estados-Membros, e foi consagrado também nos arts. $6^{\circ}$ e $13^{\circ}$ da Convenção Europeia para Proteção dos Direitos do Homem e das Liberdades Fundamentais.

A importância do referido artigo da CDFUE já havia sido levantada antes mesmo de seu caráter ser vinculativo, tamanha a importância atribuída ao direito à proteção jurisdicional efetiva. $\mathrm{O}$ dispositivo consagra no Tratado o direito mencionado, todavia o faz sem determinar alterações nos sistemas jurisdicionais já previstos nos Tratados da União ou seja, independentemente de como for a estrutura judiciária de que se fala, é preciso que aos indivíduos, ao entenderem terem seus direitos e garantias violados, seja conferida a possibilidade de buscar uma resposta do Poder Público, seja em tribunal nacional ou em tribunal da União Europeia.

Quaisquer sistemas de proteção de direitos subjetivos compõem-se de duas vertentes que se completam: a primeira tem natureza proclamatória, ela consagra o direito, enquanto a segunda tem caráter garantista e avulta o controle do respeito a tais direitos. ${ }^{5}$ É a segunda acepção que aqui merece destaque, já que de nada adianta haver um rol de direitos consagrados às pessoas se elas não tiverem meios de exercê-los ou de defendê-los de violações. Quando se priva o titular de um direito da tutela jurisdicional correspondente, é como se tudo o que lhe foi conferido por lei/norma não passasse de recomendação, já que, havendo violação ou necessidade de coerção ao cumprimento, não the haveria recurso disponível, restando apenas a possibilidade de quedar-se inerte.

Rui Moura Ramos ${ }^{6}$, ao discorrer sobre o acesso dos particulares aos tribunais europeus, explicita que, quando as Comunidades assumiram competências que anteriormente pertenciam aos Estados membros, decorreu naturalmente a consequência de o particular poder neutralizar atos comunitários que lhe causem efeitos negativos ou de reparar os prejuízos decorrentes destes atos, e explica: se dantes havia uma proteção jurídica aos particulares no plano nacional (isto em relação aos atos nacionais eivados de ilegalidade

\footnotetext{
${ }^{4}$ FERNANDES, F. O direito fundamental à ação e as suas implicações no contencioso da União Europeia pós-Tratado de Lisboa: Por um «Mecanismo Europeu de Resgate» dos Direitos dos Particulares. Cascais: Editora Principia, 2015, p.21.

${ }^{5}$ PROENÇA, C. Proteção jurisdicional efetiva na União Europeia: evolução e perspectivas (ou expectativas) futuras. Debater a Europa, n. 15, julho/dezembro 2016, p. 83.

${ }^{6}$ MOURA RAMOS, R. M. O acesso dos particulares aos Tribunais Europeus, Estudos de Direito da União Europeia, $2^{\mathrm{a}}$ ed., Coimbra: Editora GESTLEGAL, 2019, p. 437.
} 
ou danosos aos particulares), então, a partir do momento em que a tomada e edição desses mesmos atos passa para a esfera comunitária, não poderia a proteção jurídica ser diminuída.

A tutela jurisdicional efetiva é constituída por diversos elementos, dentre eles podendo-se citar o direito de defesa, a igualdade de armas, o direito de acesso aos tribunais e o direito de aconselhamento e de representação ${ }^{7}$ (termo europeu). Sobre o direito de acesso aos tribunais, o qual se põe em causa neste estudo, não basta que exista um órgão julgador à disposição das pessoas, é preciso que tal ainda detenha competência para examinar todas as questões de fato e de direito pertinentes para o litígio que é chamado a decidir ${ }^{8}$.

O sistema de jurisdição da União concebe-se com a existência de dois componentes: a estrutura nacional interna de cada Estado-Membro e a estrutura da União Europeia. Há direitos dos indivíduos que decorrem diretamente da ordem jurídica da União, e na maioria das vezes podem ser defendidos nos tribunais internos de seu Estado ${ }^{9}$, utilizando-se dos procedimentos judiciais estabelecidos pelo direito nacional, o que coaduna com o disposto no art. $19^{\circ} .1$ do Tratado da União Europeia (doravante TUE), que aduz que "Os EstadosMembros estabelecem as vias de recurso necessárias para assegurar uma tutela jurisdicional efetiva nos domínios abrangidos pelo direito da União”.

Do referido artigo emana o que se chama de princípio da autonomia processual na União Europeia, que, em síntese, pontua que cabe à ordem jurídica interna dos EstadosMembros designar os órgãos jurisdicionais competentes e regular as modalidades processuais das ações designadas a garantir os direitos conferidos aos litigantes pelo direito da União. Ainda, atribui aos Estados-Membros a responsabilidade de assegurar, em cada caso, a proteção efetiva desses direitos ${ }^{10}$.

Há então atribuição à ordem jurídica interna dos Estados-Membros para que se organize no sentido de garantir o acesso aos tribunais e a proteção efetiva dos direitos. Todavia, além disso, é dado que as modalidades processuais adotadas para tal por cada

\footnotetext{
7 Tribunal de Justiça da União Europeia, Acórdão OTIS ET AL, Processo C-199/11, de 06/01/2012, Relator A. Arabadjiev, $\quad \mathrm{n}^{\mathrm{o}} \quad 48 . \quad$ Disponível <http://curia.europa.eu/juris/document/document.jsf?text=\&docid=129323\&pageIndex=0\&doclang=PT\&mo $\underline{\text { de}=l s}>$. Acesso em 18 de junho de 2020.

${ }^{8}$ Idem, no 49.

${ }^{9}$ RAVO, L. M. The role of the Principle of Effective Judicial Protection in the EU and its Impact on National Jurisdictions. Sources of Law and Legal Protection, (Triestine Lecture; 1), EUT Edizioni Università di Trieste, 2012, p. 110.

10 MOTA DE CAMPOS, J.; MOTA DE CAMPOS, J.L.; PINTO PEREIRA, A. Manual de Direito Europeu. $7^{\mathrm{a}}$ ed., Coimbra: Coimbra Editora, 2014, p. 106.
} 
Estado não podem ser menos favoráveis do que as modalidades processuais destinadas a tutelarem direitos originários da ordem interna (princípio da equivalência), e também não podem tornar excessivamente difícil ou impossível o exercício dos direitos conferidos pela ordem jurídica da União (princípio da efetividade) ${ }^{11}$ A norma processual interna aplicar-seá então na tutela de direitos, independentemente de tais direitos serem oriundos das normas comunitárias ou das normas nacionais. É ainda preciso que as disposições nacionais não tornem impossível ou excessivamente difícil o exercício dos direitos conferidos aos particulares pela ordem jurídica da União ${ }^{12}$.

Apesar do reconhecimento de que cabe aos Estados membros tal atribuição e da construção dogmática em torno da sua parcela de responsabilidade pela tutela jurisdicional efetiva, não se pode desconsiderar a existência de situações que fogem da órbita dos tribunais nacionais, como, por exemplo, a pronúncia sobre nulidade ou invalidade de atos da União Europeia, em que há unicamente competência dos tribunais europeus.

Feitas as considerações iniciais, explicita-se que o presente trabalho se propõe a analisar os critérios de legitimidade impostos aos particulares que queiram utilizar-se do recurso de anulação contra atos da União. Para tanto, iniciar-se-á com considerações gerais sobre o recurso de anulação, para posteriormente discorrer acerca das condições de legitimidade dos particulares. Num segundo momento, serão verificadas se existem alternativas disponíveis aos particulares que sejam comparáveis, em termos de resultado, ao recurso de anulação, buscando-se analisar se os existentes parâmetros de legitimidade coexistem com o princípio da tutela jurisdicional efetiva, ou se são, em verdade, restritos demais a ponto de causarem denegação de justiça.

\section{O recurso de anulação: notas gerais}

$\mathrm{O}$ art. $263^{\circ}$ do TFUE regula o recurso de anulação (que, apesar da nomenclatura, é verdadeira ação), que visa atacar os atos da própria União Europeia, buscando a declaração de sua nulidade, com efeitos, em regra, ex tunc e erga omnes. Pode-se recorrer a ele em

\footnotetext{
${ }^{11}$ Ibidem, p. 106.

12 O Tribunal de Justiça da União Europeia, já foi chamado mais de uma vez para pronunciar-se sobre o princípio da efetiva tutela jurisdicional e sua relação com as ordens internas dos Estados, e já reconheceu a existência da relação, mencionando, por exemplo, que ela decorre inclusive do princípio da cooperação estampado no art. $4^{\circ} .3$ do TUE. Ver: Tribunal de Justiça da União Europeia, Acórdão de 16.12.1976, Rewe, 33/76, Colet., p. 813, nº 5; Tribunal de Justiça da União Europeia, Acórdão de 14.12.1995, Peterbroeck, C312/93, Colet., p. I-4599, no 12.
} 
conjecturas que visem atacar os atos eivados de incompetência, proferidos com violação de formalidades essenciais, violadores de Tratados e contaminados por desvio de $\operatorname{poder}^{13}$.

A ação é de competência dos Tribunais europeus, e prende-se com a legitimidade passiva $^{14}$, ao passo em que os demandados serão sempre as instituições autoras do ato ou os órgãos e organismos da União mencionados no referido artigo.

A União, como comunidade de direito, visou assegurar proteção e controle jurisdicional contra os atos suscetíveis à produção de efeitos jurídicos em relação a terceiros, fazendo-o inclusive em relação aos seus próprios atos. O Tratado, por meio do recurso de anulação, pretendeu pôr em funcionamento um sistema de proteção jurisdicional completa em relação aos atos das instituições comunitárias suscetíveis de produzirem efeitos jurídicos ${ }^{15}$.

O recurso de anulação tem prazo exíguo para propositura, devendo ser proposto dentro de dois meses contados da publicação do ato - caso se trate de ato sujeito à publicação ${ }^{16}$. Os atos não sujeitos à publicação devem ser atacados no prazo de dois meses a partir da notificação ou, não havendo notificação, do dia em que o recorrente tomar conhecimento do ato.

A fim de aclarar o pensamento do leitor, disseca-se brevemente o dispositivo. Os atos atacáveis mediante recurso de anulação são: a) os atos legislativos: ou seja, atos jurídicos adotados pelo processo legislativo trazido no Tratado; b) os atos do Conselho, da Comissão e do Banco Central Europeu, que não sejam recomendações ou pareceres (já que estes têm

13 Sofia Pais traz alguns exemplos de cada uma das hipóteses: incompetência, quando a União atuar em domínio em que não poderia fazê-lo (incompetência absoluta), ou quando o ato for adotado por instituição diferente da prevista no Tratado; violação de formalidades, quando por exemplo houver violação ao dever de fundamentação, ao princípio do contraditório, dos direitos de defesa, das regras de votação, do pedido de parecer previsto no Tratado; violação dos Tratados, como quando houver incumprimento da hierarquia das normas e, por último; desvio de poder, quando a autoridade administrativa utilizar-se dos seus poderes com objetivo diferente daquele para que lhe foram conferidos.

OLIVEIRA PAIS, S. Assimetrias no Contencioso da União Europeia depois de Lisboa e a Sensação de Dèjà Vu. Estudos de homenagem ao Prof. Doutor Jorge Miranda. Vol. 5, Coimbra: Coimbra Editora, 2012. p. 559574.

14 RANGEL DE MESQUITA, M. J. Introdução ao Contencioso da União Europeia. Coimbra: Editora Almedina, 2015, p. 132.

${ }^{15}$ Como mencionado nas considerações iniciais, já era o entendimento do Tribunal inclusive antes da previsão expressa advinda do Tratado de Lisboa, conforme Acórdão do Tribunal de Justiça da União Europeia, Acórdão de 27-09-1988, PE/Conselho (Comitologia), proc. 302/87, Col., p. 5615, cons. 20.

${ }^{16} \mathrm{O}$ art. $81^{\circ}, \mathrm{n}^{\mathrm{o}} 1$ do regulamento de Processo do TJUE e $102^{\circ}, \mathrm{n}^{\circ} 1^{\circ}$ do Regulamento de Processo do Tribunal Geral mencionam que o prazo de dois meses começa a contar a partir do termo do $14^{\circ}$ dia subsequente àquele em que o ato tenha sido publicado. Ao prazo é acrescida ainda a dilação de 10 dias em razão da distância, sendo o prazo consequentemente mais longo do que os dois meses estampados no TFUE. 
caráter não vinculativo); c) os atos do Parlamento Europeu e do Conselho Europeu destinados a produzir efeitos jurídicos em relação a terceiros; d) atos dos órgãos ou organismos da União destinados a produzir efeitos jurídicos em relação a terceiro.

A característica extraível de todos os atos atacáveis é que eles são aptos a produzirem efeitos jurídicos obrigatórios. É no conteúdo do ato que se deve prestar atenção: as disposições tomadas pelas instituições devem ser destinadas a produzirem efeitos jurídicos obrigatórios, afetando interesses e modificando de forma caracterizada certas situações jurídicas. Se um ato contiver partes distintas, só podem ser impugnadas as partes do ato que produzam efeitos jurídicos obrigatórios; ou seja, o recurso será admissível contra essa parte do ato e inadmissível contra partes que não modifica a situação jurídica do recorrente.

Quanto a quem pode recorrer, os recorrentes podem ser classificados como privilegiados, semiprivilegiados ou ordinários.

Chamam-se de recorrentes privilegiados os Estados-membros, o Parlamento Europeu, o Conselho Europeu e a Comissão, pois, conforme redação do art. $263^{\circ}$ do TFUE, podem atacar quaisquer atos passíveis do recurso, independentemente de terem um interesse direto ou de ter-lhe o ato causado danos. Ou seja, tais recorrentes podem impugnar atos que causem efeitos jurídicos, ainda que não na sua própria esfera ${ }^{17}$. Os privilegiados podem ainda utilizarem-se de todos os motivos de nulidade previstos no Tratado: incompetência, violação de formalidades essenciais, violação dos Tratados ou de qualquer norma jurídica relativa a sua aplicação, ou em desvio de poder.

O Tribunal de Contas, o Banco Central Europeu e o Comitê das Regiões, apesar de instituições da União, não dispõem dos mesmos privilégios dos mencionados acima, posto que somente poderão utilizar-se da ação para salvaguardarem suas prerrogativas institucionais, sendo considerados semiprivilegiados.

É à última categoria — dos recorrentes ordinários — que se dará maior relevo, sendo o objeto do presente estudo. Eles são assim chamados ante as restrições que lhe são impostas para o uso da ação, e é nessa categoria que os particulares se enquadram.

$\mathrm{O}$ art. $263^{\circ} .4$ TFUE diz que qualquer pessoa singular ou coletiva pode interpor, nas condições previstas nos números anteriores ao $4^{\circ}$, recursos contra os atos de que seja destinatária ou que lhe digam direta e individualmente respeito, bem como contra os atos

\footnotetext{
${ }^{17}$ J. D. COOKE. Locus Standi of Private Parties under Article 173 (4). Irish J. European L., 6, 4, 1997, p. 5.
} 
regulamentares que lhe digam diretamente respeito e não necessitem de medidas de execução. Quando os particulares forem destinatários do ato, não há maiores dúvidas acerca da possibilidade de manejo do recurso de anulação, razões pela qual passa-se ao estudo das demais possibilidades.

\section{Legitimidade dos particulares: atos que digam "direta e individualmente a respeito" a um particular e a fixação do critério Plaumann}

A principal celeuma quanto à legitimidade refere-se aos atos que os particulares visam atacar por se entenderem como "direta e individualmente afetados", posto que a definição e alcance da expressão não são trazidas pelo Tratado, cabendo à doutrina e (principalmente) ao Tribunal a delimitação do que são atos que tratem direta e individualmente respeito a alguém.

Quanto à afetação direta, entende-se que a palavra direta é construída como antônimo de indireta, de forma que um particular será afetado diretamente quando os efeitos no seu campo jurídico decorrerem do ato comunitário, e não de um ato nacional eventualmente decorrente - ou seja, é o ato da União que causa a modificação danosa imediatamente na esfera jurídica do particular $^{18}$. Não há maiores problemas no que diz respeito à afetação direta, motivo pelo qual passa-se à deliberação sobre o segundo requisito exigido pelo Tratado, o de "individualmente afetado".

A interpretação do Tribunal sobre a abrangência do termo se deu no caso envolvendo a Plaumann \& $C o^{19}$, empresa alemã dedicada à importação de clementinas de outros países. No caso, a Plaumann \& Co, na sua condição de importadora de clementinas, utilizou-se do recurso de anulação contra a decisão N.SIII 03079 da Comissão (à época CEE), datada de 22 de maio de 1962. A decisão era dirigida à República Federativa da Alemanha (RFA), e recusava à RFA a autorização para suspender parcialmente os direitos aduaneiros aplicáveis às mandarinas e clementinas frescas importadas de países terceiros.

18 CORTÉS MARTÍN, J. M. Afectación individual (230.4 CE): ¿um obstáculo infranqueable para la admisibilidad del recurso de anulación de los particulares?, Revista de Derecho Comunitario Europeo, 2003, p. 1124.

19 Tribunal de Justiça, Plaumann \& Co, Acórdão de 15/07/1963, processo 25/62, disponível em < https://eurlex.europa.eu/legal-content/PT/TXT/PDF/?uri=CELEX:61962CJ0025\&from=DE>. Acesso em 18 de junho de 2020.

A decisão foi proferida com base no antigo art. $173^{\circ}$ do Tratado CEE, que também se utilizava da expressão "direta e individualmente respeito". 
Por não ser destinatária do ato, precisou-se deliberar sobre se era então a Plauman \& Co afetada direta e individualmente. O Tribunal inadmitiu o recurso, definindo um critério de legitimidade que passou a ser chamado de critério Plaumann, concluindo que:

(...) os particulares que não sejam destinatários de uma decisão só podem afirmar que esta lhes diz individualmente respeito se os afetar devido a "certas qualidades que lhes são próprias ou a uma situação de facto que os caracteriza em relação a qualquer outra pessoa e assim os individualiza de maneira análoga à do destinatário. ${ }^{20}$

Em razão da Plaumann \& Co ser afetada pela sua condição de importadora de clementinas, ou seja, pela sua atividade comercial, o Tribunal entendeu que não havia afetação individual diferenciadora da empresa de todos os demais, já que essa atividade comercial poderia ser exercida por qualquer pessoa, impossibilitando a caracterização do particular de maneira análoga ao destinatário em relação à decisão.

Do critério fixado decorre a necessidade de que o recorrente tenha particularidades em relação ao ato que o possam tornar comparável ao próprio destinatário ${ }^{21}$. É preciso que o particular seja atingido de forma única — que ninguém mais o seja — para poder utilizarse do recurso de anulação nessas condições. Então, quanto maior for o número de atingidos, mais difícil vai ser a alegação de que o atingimento foi de forma completamente diferente dos demais, e menores as chances de uso do recurso.

A doutrina percebeu que dificilmente haverá a aceitação das pessoas jurídicas atuantes no mercado como legitimadas, já que a tendência é de que existam outras empresas, constituídas ou passíveis de constituição, dedicadas à mesma atividade, como explica Cortés Martin $^{22}$. Isto pois a inadmissibilidade se baseia, por muitas vezes, justamente no fato de o particular ser afetado pelo ato em decorrência da sua condição de agricultor, pescador, exportador, de forma que qualquer outro operador econômico do ramo pode se encontrar atualmente ou potencialmente em situação idêntica.

Sobre os particulares atuantes no mercado, houve certa evolução no que diz respeito aos particulares detentores de direitos específicos, como se pôde observar no Caso Codorniu

\footnotetext{
${ }^{20}$ Ibidem, p. 284.

${ }^{21}$ MOURA RAMOS, R. M. O Tribunal de Justiça e o Acesso dos Particulares à Jurisdição da União após as alterações decorrentes do Tratado de Lisboa. Estudos de Direito da União Europeia. $2^{\mathrm{a}}$ ed. Coimbra: Editora GESTLEGAL, 2019, p. 296.

${ }^{22}$ CORTÉS MARTIN, Afectación..., op. cit., p.1125.
} 
$(1994)^{23}$. A autora/recorrente propôs recurso de anulação contra o Regulamento no 2045/89, que determinava que o termo crémant só poderia ser usado por vinhos espumantes de origem de certos locais da França e Luxemburgo, e que detivessem particular qualidade. A recorrente era espanhola, produzia vinhos espumantes, e detinha marca registrada desde 1924, marca cuja palavra cremánt constava (Gran Cremánt de Codorniu). Apesar de mais empresas, à época, produzirem vinhos utilizando-se da expressão cremánt, somente a Codorniu tinha a marca registrada desde 1924, o que fez com que o recurso fosse admitido, já que o direito de propriedade seria afetado de forma a anular sua própria existência, não consubstanciando-se em mera redução potencial da marca ou diminuição de seu valor de mercado, mas em verdadeira impossibilidade de ela continuar a existir.

No caso mencionado, a admissão do recurso não se decorreu por o Tribunal ter afastado o critério Plaumann, mas sim por ter entendido haver um amoldamento a ele. Entendeu-se que a recorrente atendia ao requisito de individualmente afetada anteriormente definido, já que a disposição pertinente do regulamento impedi-la-ia de usar a sua marca registrada há tantas décadas, o que não ocorria com as demais produtoras de vinho. Entendeu-se então que a empresa provou a existência de situação de fato que a diferenciava de todos os demais produtores, individualizando-a como se fosse própria destinatária do ato $^{24}$.

Há também fatores de admissibilidade nos casos em que, para as instituições, existia um dever prévio de, ao adotar o ato de natureza geral, levar em conta as circunstâncias específicas do recorrente. Neste contexto, a jurisprudência é no sentido de que o fato de uma pessoa participar, de uma forma ou de outra, no processo que conduz à adoção de um ato comunitário, é suscetível de individualizar essa pessoa relativamente ao ato em questão, desde que a regulamentação comunitária aplicável lhe conceda certas garantias processuais $^{25}$.

\footnotetext{
${ }^{23}$ Tribunal de Justiça da União Europeia, Acórdão de 18 de Maio de 1994, Codorniu SA vs. Conselho da União Europeia, processo C-309/89, C-309/89, Colect., p. I-1853.

${ }^{24}$ Para José Martin Cortés, este foi um giro do Tribunal, já que se admitiu o exame da relação especial existente entre a situação do demandante e a medida impugnada, fazendo prevalecer uma interpretação ampla dos interesses individuais sobre a natureza regulamentar do ato impugnado. Em Afectación Individual..., op. cit, p. 1130 .

${ }^{25}$ Tribunal de Primeira Instância, Acórdão de 13 de Dezembro de 1995, Exporteurs in Levende Varkens e o./Comissão, T-481/93 e T-484/93, Colect., p. II-2941, n. ${ }^{\circ}$ 50; Tribunal de Primeira Instância, Despacho de 9 de Agosto de 1995, Greenpeace e o./Comissão, T-585/93, Colect., p. II-2205, números 56 e 63.
} 
Por último, a afetação individual fica também preenchida: quando o recorrente for identificado em atos do Conselho ou da Comissão ${ }^{26}$; quando o particular foi objeto de inspeções e participou do processo de edição (por exemplo, apresentando observações), ou seja, quando fez parte de um círculo fechado de pessoas ${ }^{27}$.

Desta forma, apesar de terem surgido julgados conferindo legitimidade aos particulares em certas situações, o conceito de afetação individual delineado no caso Plaumann continua a ser usado e constantemente referido, sendo raras as possibilidades de um particular preencher a afetação de forma análoga ao destinatário.

\section{As conclusões do advogado geral F. G. Jacobs no caso Unión de Pequeños Agricultores e o julgamento do TPI no caso Jégo-Quére}

Houve uma esperança de que a interpretação restritiva se modificasse, nos casos que se narram a seguir.

A União de Pequenos Agricultores (doravante UPA), associação profissional que assegura a defesa dos interesses de pequenas empresas agrícolas espanholas, ajuizou perante o Tribunal de Primeira Instância (TPI) europeu um recurso de anulação em 20 de outubro de 1998, contra parte do Regulamento $\mathrm{n}^{\mathrm{o}} 1638 / 98^{28}$, que reformava alguns aspectos da organização comum do mercado de azeite. O TPI, em 23 de novembro de 1999, julgou inadmissível o recurso, pontuando que não havia enquadramento da UPA nos critérios considerados como "direta e individualmente afetado"29.

Como já feito antes, o TPI reconheceu que o ato tinha natureza normativa, na medida em que se aplicava de modo geral e abstrato a situações de fato ou de direito definidas de maneira objetiva. Apesar disso, admitiu a possibilidade de que, mesmo os atos normativos que se aplicam à generalidade dos operadores, podem, em certos casos, dizerem individualmente respeito a alguns deles.

\footnotetext{
26 Tribunal de Justiça, Acórdão de 16 de maio de 1991, Extramet Industrie SA contra Conselho das Comunidades Europeias, Processo 358/89, números 14 e 15 . Disponível em < https://eurlex.europa.eu/resource.html?uri=cellar:16ce615b-12d8-415e-8b66-

6b94ab7fd0db.0009.02/DOC_2\&format=PDF>. Acesso em 18 de junho de 2020.

${ }^{27}$ PAIS., Assimetrias..., op. cit., p. 566.

${ }^{28}$ Regulamento (CE) no 1638/98 do Conselho, de 20 de julho de 1998, que altera o Regulamento n ${ }^{\circ} 136 / 66 / C E E$ que estabelece uma organização comum de mercado no setor das matérias gordas (JO L 210, p. 32).

${ }^{29}$ Tribunal de Pequena Instância, Despacho de 23 de novembro de 1999, Unión de Pequeños Agricultores (UPA)/ Conselho, 173/98, Colect., p. II-3357.
} 
A UPA recorreu do despacho do TPI, e em sua defesa mencionou, dentre outros argumentos, que havia caráter de ordem pública no exame de legalidade do regulamento, e que, caso não admitida como parte legítima no recurso de anulação, ela não poderia questionar o ato noutro Tribunal, logo não se beneficiaria de tutela jurisdicional efetiva. Segundo a UPA, os tribunais só poderiam julgar um recurso inadmissível quando resultasse da apreciação que o particular tinha meios de levar a questão aos tribunais nacionais.

A Comissão apresentou seus argumentos, aduzindo que os fundamentos da UPA se prendiam à violação do princípio da tutela jurisdicional efetiva, o que não alteraria a questão da legitimidade enunciada com base nos critérios do Tratado. Assim, a Comissão reconheceu a existência do direito à tutela efetiva no direito comunitário, mas aduziu que o Tratado estabeleceu um sistema completo de vias recursais, com uma gama de hipóteses de permissão aos particulares para impugnarem atos de caráter geral junto aos tribunais nacionais, destacando o reenvio prejudicial ao Tribunal de Justiça.

Quanto à alegada violação ao acesso à justiça, a Comissão mencionou que, a seu ver, a UPA tinha meios de agir, podendo: a) dirigir à administração espanhola um pedido de um dos tipos de ajuda abolidos pelo regulamento, no sentido de contestar a recusa explícita ou implícita da administração de acolher tal pedido; b) levantar a questão da alegada violação do seu direito fundamental a uma tutela jurisdicional efetiva perante o Tribunal Constitucional espanhol ou; c) processar a administração espanhola pelas perdas e danos decorrentes de tal violação. 
$\mathrm{O}$ advogado geral ${ }^{30}$ F. G. Jacobs apresentou suas conclusões em 21 de março de $2002^{31}$, nas quais sugeriu uma mudança no entendimento de afetação individual, nos termos em que se passa a expor.

Após deliberar sobre a existência de direito à tutela jurisdicional efetiva, fez análise do mecanismo de reenvio e seu preenchimento ou não da tutela efetiva. Ele pontuou que os órgãos jurisdicionais nacionais não têm competência para declarar a invalidade de medidas de direito comunitário (consideração 41), sendo limitado a eles verificação dos argumentos dos particulares, no sentido de se eles levantam ou não dúvidas suficientes quanto à validade da medida impugnada, casos em que se justifica um pedido ao Tribunal de Justiça de decisão a título prejudicial.

Jacobs mencionou que, além de não haver competência para os tribunais particulares declararem invalidade de normas comunitárias, a regra é a discricionaridade ao juiz nacional para fazer o reenvio, podendo ele negar o pedido do particular para que o faça ${ }^{32}$. Ademais, citou que é o juiz que seleciona o objeto e alcance da dúvida, de forma que não necessariamente o que for suscitado ao Tribunal coincidirá com os termos trazidos pelo particular.

O advogado-geral também pontuou que os recursos nos sistemas jurisdicionais nacionais são suscetíveis de implicar longas demoras, que podem, por si só, serem incompatíveis com o princípio da tutela jurisdicional efetiva e com a exigência da segurança jurídica (consideração 42).

\footnotetext{
${ }^{30}$ Lembrando que a função do Advogado-Geral do TJUE não é a de representar a parte, como comumente é visto. Para além dos 28 juízes, integram o Tribunal de Justiça onze advogados-gerais, designados de comum acordo pelos governos dos Estados-Membros, após consulta de um comité encarregado de dar parecer sobre a adequação dos candidatos propostos ao exercício das funções em causa.

Os seus mandatos são de seis anos, renováveis. São escolhidos de entre pessoas que ofereçam todas as garantias de independência e tenham a capacidade requerida para o exercício, nos respetivos países, de altas funções jurisdicionais ou com reconhecida competência.

Para cada processo são nomeados um juiz-relator e um advogado-geral.

$\mathrm{O}$ advogado-geral assiste o Tribunal de Justiça, com a missão de propor, com toda a independência e imparcialidade, uma solução jurídica nos processos que lhe são atribuídos. Estas "conclusões" não vinculam o Tribunal de Justiça, que não segue necessariamente o parecer do advogado-geral. Com base nas conclusões do advogado-geral, o coletivo de juízes delibera e profere o seu acórdão.

Disponível em < http://euroogle.com/dicionario.asp?definition=1204>. Acesso em 18 de junho de 2020.

${ }^{31}$ Conclusões do Advogado-Geral F.G Jabobs no caso Unión de Pequeños Agricultores (UPA)/ Conselho, 173/98, apresentadas em 21 de março de 2002. Disponível em: <https://eur-lex.europa.eu/legalcontent/PT/TXT/PDF/?uri=CELEX:62000CC0050\&from=FR>. Acesso em 28 de agosto de 2019.

${ }^{32}$ Há algumas exceções, em que o reenvio é obrigatório, previstas no art. 267 do TFUE.
} 
À época das considerações do advogado, mencionou-se que poderia ser impossível aos particulares a impugnação de medidas comunitárias que não demandassem quaisquer atos posteriores de implementação por parte das autoridades nacionais: o particular afetado diretamente por medida comunitária não deteria legitimidade para recurso de anulação, cabendo a ele primeiramente violar a norma, para, somente quando fosse se defender num processo penal ou cível a ele dirigido, questionar a sua validade. A solução esdrúxula e única via parecia ser que o particular primeiramente violasse a lei, para só então poder acessar a justiça (consideração 43).

Houve ainda a defesa da tese de que o recurso de anulação é muito mais adequado para decidir questões de validade do que o reenvio prejudicial, já que: no recurso de anulação, a instituição que adotou a medida impugnada é parte no processo do começo ao fim, com ampla troca de articulados e verdadeiro contraditório (consideração 46); os recursos diretos devem ser propostos no prazo exíguo de 02 meses previsto no Tratado, e, nos órgãos nacionais, o reenvio que questiona validade pode ser feito a qualquer momento (sendo preferível, por razões de segurança jurídica, que os atos comunitários sejam reconhecidos como válidos ou inválidos o mais rapidamente possível após serem adotados).

Ele reconheceu que de fato há defasagem na tutela jurisdicional aos particulares. Todavia, rogou que, no texto do TFUE, dispõe-se que serão admitidos os recursos de anulação quando o ato disser direta e individualmente respeito ao particular, sendo este o requisito de legitimidade imposto. Ou seja, apesar de entender haver falhas na tutela jurisdicional efetiva, não acredita que tal falha é apta a alterar o texto do Tratado e conferir legitimidade não prevista legalmente.

Além de entender que a ausência de efetividade na tutela jurisdicional não ser capaz de ampliar o rol de legitimados, Jacobs alerta para a impossibilidade de o Tribunal de Justiça analisar, em sede de recurso de anulação (por falta de competência e também de condições), se os tribunais nacionais possibilitam alternativas satisfatórias de acesso à justiça e de questionamentos judiciais dos atos. Este não seria o procedimento adequado, já que haveria indesejada análise meramente superficial em relação à organização e sistema jurídico de cada país, considerando que o objetivo do recurso de anulação é outro. Somado a isto, correrse-ia risco de afronta à igualdade de tratamento, visto que o particular de um Estado teria 
direito a interpor recurso de anulação, e não o teria o particular doutro país, afetado pelo mesmo ato.

A solução da celeuma para o advogado-geral não estaria na introdução de observância prévia do sistema jurídico de cada país, mas sim na mudança jurisprudencial do próprio Tribunal sobre a interpretação da expressão utilizada no Tratado. Ele defendeu que, para satisfazer os critérios de amplo acesso à jurisdição sem necessidade de afrontar o texto escrito do Tratado, o entendimento do Tribunal de Justiça precisaria alterar-se, aceitando que "uma medida comunitária diz individualmente respeito a uma pessoa quando, em razão das circunstâncias particulares desta, a medida afeta ou é suscetível de afetar negativa e substancialmente seus interesses" (consideração 60), mencionando que muitas vezes uma medida afeta negativamente um grande número de particulares, causando danos generalizados, o que deveria ser fator suficiente para aceitar a impugnação direta por um ou por mais de um desses particulares (consideração 59).

Com a adoção desse critério de superação dos parâmetros Plaumann, o advogado entendeu que assegurar-se-ia não só que os recorrentes particulares direta e negativamente afetados pudessem questionar as medidas comunitárias, mas que, além disso, permitir-se-ia que as questões de validade dessas medidas fossem tratadas no contexto do processo mais adequado, qual seja o recurso de anulação (consideração 63), deslocando a ênfase do controle jurisdicional das meras questões de admissibilidade para as questões de fundo. ${ }^{33}$

Sobre um eventual excesso de processos no Tribunal, oriundo da ampliação do rol de legitimados, Jacobs explicitou que a regra tem sido, em sistemas jurídicos dentro e fora da União, do alargamento dos requisitos de legitimidade (considerações 79 e 85), com o fim de promover o verdadeiro acesso à tutela jurisdicional, e que não seria todo particular que se enquadraria nas condições necessárias, já que eles continuariam a ter que preencher a questão da afetação direta e individual, além de terem que intentar a ação num prazo de dois meses. E pontuou que, ainda que houvesse real aumento no número de ações, elas impugnariam a mesma medida, possibilitando o tratamento conjunto de processos ou seleção de processos-modelos (consideração 80) .

\footnotetext{
${ }^{33} \mathrm{O}$ advogado reconheceu que há sim a necessidade de proteção do processo legislativo das intervenções judiciais indevidas, mas pontuou que essa proteção se atinge melhor por meio de critérios substanciais de controle jurisdicional, que concedam às instituições uma margem de apreciação no exercício dos poderes, do que por meio de uso de regras rígidas de admissibilidade, já que estas últimas excluem recorrentes sem sequer considerar o mérito do que dizem
} 
O advogado geral entendeu que era o momento adequado de revisão da jurisprudência do Tribunal, e concluiu que o melhor e mais satisfatório meio de solucionar o ponto seria reconhecer que uma medida comunitária diz individualmente respeito a uma pessoa quando afeta ou é suscetível a afetar negativa e substancialmente os seus interesses. Desta forma, nas conclusões, Jacobs entendeu que essa solução proporcionaria um acesso direto ao tribunal competente para solucionar a questão, evitando-se casos de denegação de justiça; resolveria a anomalia existente na jurisprudência de que quanto maior for o número de pessoas afetadas, menos provável é a existência de um controle jurisdicional efetivo; deslocaria a ênfase dos julgamentos da mera admissibilidade para as questões de fundo; seguiria a tendência geral da jurisprudência de alargar o âmbito da tutela jurisdicional em resposta ao aumento dos poderes das instituições comunitárias.

Somadas às considerações de Jacobs, a esperança de evolução na interpretação também teve seu momento noutro caso. Na pendência de julgamento pelo Tribunal de Justiça após as apresentações das conclusões do advogado geral no caso UPA, foi proferido no caso Jégo-Quére ${ }^{34}$ um acórdão pelo TPI com ares de mudança jurisprudencial.

A sociedade de armação de pesca Jégo-Quére, empresa francesa, ajuizou pedido de anulação contra um regulamento da Comissão ${ }^{35}$ que visava medidas para recuperar a unidade populacional de pescada em certas zonas, principalmente as pescadas juvenis, impondo condições para controle da atividade dos navios de pesca e malhagem mínima aos navio (variante conforme a zona), por ser possuidora de navios com malhagem inferior à estabelecida.

A defesa da Comissão foi justamente no sentido do que até então era a jurisprudência do Tribunal Geral, ou seja, de que a proibição geral de malhagens inferiores a certa medida aplicava-se a todos que pescam no mar céltico, não entendendo ter sido individualizada a situação da recorrente.

\footnotetext{
${ }^{34}$ Acórdão do Tribunal de Primeira Instância (Primeira Secção Alargada) de 3 de Maio de 2002. - Jégo-Quéré \& Cie SA contra Comissão das Comunidades Europeias. Processo T-177/01. Coletânea da Jurisprudência 2002 página II-02365

${ }_{35}$ Especificamente contra os arts. $3 .^{\circ}$, alínea d), e 5. ${ }^{\circ}$ do Regulamento (CE) n. ${ }^{\circ}$ 1162/2001 da Comissão, de 14 de Junho de 2001.

A empresa, apesar de ser francesa, exercia atividade permanente no sul da Irlanda, região de zona afetada pelo regulamento, e era detentora de quatro navios com rede de $80 \mathrm{~mm}$ - inferiores ao mínimo de $100 \mathrm{~mm}$ estabelecido para a zona.
} 
Jégo-Quére, por sua vez, alegou que a inadmissibilidade do seu recurso de anulação a privaria de quaisquer vias de defesa, uma vez que não existia um ato adotado em nível nacional suscetível de ser impugnado nos tribunais. Invocou o art. $6 .^{\circ}$ da Convenção Europeia para Proteção dos Direitos do Homem e das Liberdades Fundamentais (CEDH) ${ }^{36}$, pedindo que à luz desta disposição fosse realizada interpretação extensiva da legitimidade dos particulares para o recurso de anulação.

O TPI proferiu acórdão admitindo o recurso de anulação, em 03 de maio de 2002 . Na análise do caso, o TPI explanou que se a afetação individual continuasse entendida como até então o era, a recorrente não seria legítima; todavia, decidiu pela necessidade de alteração no entendimento do termo, pelas razões que a seguir se expõe.

Sobre a existência ou não de recurso jurisdicional efetivo no caso da recorrente, explanou que Jégo-Quére não poderia se utilizar do reenvio prejudicial, já que não existiam medidas de execução aptas a ensejarem ação nos tribunais nacionais, retomando o argumento de Jacobs, no sentido de não ser razoável esperar que o particular violasse uma disposição para, só então, em sede de defesa, impugnar o ato da União.

Quanto à ação de indenização, apontada pela Comissão como suposta concretizadora do acesso à justiça efetivo no presente caso, o TPI entendeu que não era a via mais adequada, já que não afastava um ato da ordem jurídica, ainda que ele fosse considerado ilegal. Também aduziu que a ação de indenização estava sujeita a condições de admissibilidade e de mérito diferentes das que regem o recurso de anulação e, portanto, não colocava o órgão jurisdicional comunitário em condições de exercer, em toda a sua dimensão, a fiscalização da legalidade que tem por missão efetuar.

Assim, entendeu o Tribunal que não havia proteção efetiva ao particular, mas que este fator, por si só, não era apto a alterar as condições de legitimidade previstas no Tratado. Não obstante, remetendo-se às conclusões do advogado-geral F. G. Jacobs no processo UPA, reforçou que não existiam razões legais imperiosas para assumir que o conceito de pessoa a quem um ato diz individualmente é o de essa pessoa ser individualizada de modo análogo ao de um destinatário. Por isto, admitiu o recurso e determinou seu prosseguimento, concluindo

\footnotetext{
${ }^{36}$ Art. $6^{\circ} 1$ : Qualquer pessoa tem direito a que a sua causa seja examinada, equitativa e publicamente, num prazo razoável por um tribunal independente e imparcial, estabelecido pela lei, o qual decidirá, quer sobre a determinação dos seus direitos e obrigações de carácter civil, quer sobre o fundamento de qualquer acusação em matéria penal dirigida contra ela (...).
} 
que a fim de assegurar uma proteção jurisdicional efetiva dos particulares, deve considerarse que uma disposição comunitária de carácter geral que diz diretamente respeito a uma pessoa singular ou coletiva lhe diz individualmente respeito se a disposição em questão afetar, de forma certa e atual, a sua situação jurídica, restringindo os seus direitos ou impondo-lhe obrigações.

Há diferença notável entre a sugestão do advogado geral Jacobs para a abrangência da afetação individual e a decisão do TPI: a primeira permitia a legitimação de todos aqueles que sofressem afetações econômicas graves como consequência da norma comunitária, além de sugerir a permissão da individualização do demandante não só se a medida tivesse afetado sua situação de maneira atual, mas também de forma potencial; a segunda, sugerida pelo TPI, mostrou-se mais estreita, na medida que se baseou sobre os efeitos que a medida tinha sobre a posição legal da pessoa, devendo o demandante demonstrar que o ato comunitário restringia seus direitos ou lhe impunha obrigações, restando necessário ainda que o efeito fosse definitivo e imediato, excluindo a possibilidade de efeito potencial ${ }^{37}$.

Fazendo breve síntese cronológica, teve-se que em 21 de março de 2002 o advogado Jacobs apresentou perante o TJ conclusões favoráveis à mudança jurisprudencial no caso UPA. Em 03 de maio de 2002 o TPI admitiu o recurso de anulação no caso Jégo-Quére, visando alteração do critério de afetação jurisprudencial.

Apesar dessa tentativa de giro na jurisprudência, proferiu-se acórdão pelo TJ no caso UPA em 25 de julho de $2002^{38}$, em que não foram acatadas as conclusões do advogado-geral Jacobs. O acórdão reconheceu o direito dos particulares à tutela jurisdicional efetiva, todavia defendeu que o Tratado é composto por um sistema completo de vias jurisdicionais, competindo aos Estados-Membros a previsão de vias de recurso e meios processuais que permitam assegurar tal direito, entendendo ainda que o fato de haver ou não medida nacional conferindo acesso aos particulares não é parâmetro à conferência de legitimidade.

O Tribunal reafirmou e concluiu que uma disposição só pode dizer individualmente respeito a uma pessoa singular ou a uma pessoa coletiva se a atingir em razão de determinadas qualidades que lhe são específicas ou em razão de uma situação de facto que

\footnotetext{
${ }^{37}$ CORTÊS MARTÍN., Afectación..., op. cit., p.1143.

${ }^{38}$ Acórdão do Tribunal de 25-07-2002- Unión de Pequeños Agricultores contra Conselho da União Europeia. Processo C-50/00 P. Disponível em $<$ https://eur-lex.europa.eu/legalcontent/EN/TXT/PDF/?uri=CELEX:62000CJ0050\&from=PT> . Acesso em 18 de junho de 2020.
} 
a caracteriza em relação a qualquer outra pessoa e, por isso, a individualiza de modo análogo ao do destinatário - o que não era o caso, já que a empresa era afetada em razão da sua qualidade objetiva de atuante no mercado de azeite, o que poderia dizer respeito a qualquer outro operador econômico que se encontrasse, atual ou potencialmente, em situação idêntica.

Por fim, o TJ fez um chamado aos Estados, para que, se assim entendessem, utilizassem de seu poder de alteração do Tratado e reformassem o sistema atualmente em vigor.

Após a decisão do TJ no caso UPA, sobreveio acordão do TJ no caso Jégo-Quére, que derrubou a decisão do TPI e inadmitiu o recurso de anulação, reafirmado o seu entendimento já sedimentado do critério Plaumann ${ }^{39}$.

\section{Legitimidade dos particulares: quanto aos atos regulamentares que lhe digam diretamente respeito e não necessitem de medidas de execução}

Uma alteração promovida pelo Tratado de Lisboa quanto à legitimidade dos particulares diz respeito à segunda hipótese prevista no art. $263^{\circ} .4$, que aduz que podem interpor recurso de anulação "as pessoas singulares ou coletivas contra os atos regulamentares que lhe digam diretamente respeito, e que não necessitem de medidas de execução".

Dispensou-se nessa situação a exigência de afetação individual até então exigida, abrindo-se via à sindicabilidade de atos de alcance geral que produzam efeitos em relação aos particulares, bastando ao particular que demonstre que o ato produz efeitos diretos na sua situação jurídica, e que a aplicação se reveste de caráter automático decorrente só da regulamentação da União, sem necessidade de uso de quaisquer regras executivas intermediárias.

Essa hipótese corrigiu, supostamente, algo que há muito era falho, que era o fato de os particulares afetados por um ato regulamentar - que não necessita de medida de execução

\footnotetext{
${ }^{39}$ Acórdão do Tribunal de Justiça (Sexta Secção), 01-04-2004, processo C-263/02 P. Disponível em https://eur-lex.europa.eu/legal-content/EN/TXT/PDF/?uri=CELEX:62002CJ0263\&from=PT. Acesso em $18 \mathrm{de}$ junho de 2020.
} 
- virem-se obrigados a primeiramente infringir o ato, para somente, na sua defesa, suscitar a invalidade ${ }^{40}$, já que não dispunham, como regra, de afetação individual ${ }^{41}$.

O Tratado não deixou claro a que se refere quando escreve atos regulamentares e, para piorar o cenário, os atos da União são consagrados somente como atos legislativos ${ }^{42}$, atos delegados e atos de execução ${ }^{43}$, deixando à doutrina e jurisprudência a necessidade de aclarar o que são atos regulamentares.

A celeuma no debate deu-se, principalmente, porque o projeto de "Tratado Constitucional à União Europeia" (doravante Tratado Constitucional), ao pretender introduzir uma hierarquia de atos em razão da respectiva função paramétrica e reguladora, tentou ajustar o estatuto da União à função normativa primária e função normativa secundária, isto é, à distinção entre função legislativa e função executiva ${ }^{44}$, tendo-o feito da seguinte maneira: fez a distinção entre atos legislativos da União (lei europeia e lei-quadro europeia) e atos não legislativos da União (regulamento europeu, decisão europeia, recomendações e pareceres $)^{45}$. O mesmo Tratado Constitucional trouxe a possibilidade de os particulares utilizarem-se, sem preenchimento do requisito de afetação direta, do recurso de anulação contra atos regulamentares que lhe dissessem diretamente respeito e que não carecessem de medidas de execução ${ }^{46}$.

Com o Tratado de Lisboa consagrou-se, inclusive com a mesma nomenclatura, a possibilidade prevista no Tratado Constitucional de particulares não afetados diretamente usarem do recurso de anulação contra atos regulamentares que não carecessem de medidas de execução. Todavia, não se seguiu a nomenclatura prevista no Tratado Constitucional para os atos da União, tendo sido mantido o ponto de que os atos são só os legislativos, delegados e executivos. Ou seja, não restou tão claro pelo Tratado de Lisboa - como havia sido feito no Tratado Constitucional - em que categoria se enquadram tais atos regulamentares.

\footnotetext{
${ }^{40}$ CORTÉS MARTIN., Afectación, op. cit., p.1133. O autor comenta o recurso de anulação antes da inclusão dessa possibilidade pelo Tratado de Lisboa. Ainda, as conclusões do advogado geral Jacobs e a decisão do TPI no caso Jego Quere.

${ }^{41}$ Como se verá no capítulo 04.

${ }^{42}$ Saliente-se que os atos legislativos são assim considerados em razão do critério formal - são atos legislativos os atos aprovados por processo legislativo, seja ele ordinário ou especial, conforme estabelecido no art. $289^{\circ}$, par. $3^{\circ}$, do TFUE.

${ }^{43}$ Vide arts. $289^{\circ}, n^{\circ} 3,290^{\circ}, 291^{\circ}$ do TFUE.

${ }^{44}$ PAES MARQUES, F. O Conceito de Acto Legislativo no Direito da União Europeia. Estudos de homenagem ao Prof. Doutor Jorge Miranda. Vol. 5. Coimbra: Coimbra Editora, 2012. p. 127.

${ }^{45}$ Definindo os atos jurídicos da União, no art. I-33.

${ }^{46}$ Art. III-365, no 4 do TECE.
} 
O atual TFUE diz que regulamentos podem resultar de processo legislativo ordinário ou especial. Então a expressão atos regulamentares do art. $263^{\circ} .4$ refere-se somente aos que advém da função administrativa, ou doutro modo abrange também os de natureza legislativa?

A doutrina dividiu-se. Há os que entendem que a categoria de atos regulamentares abrange todos os regulamentos, o que coaduna melhor com o princípio da tutela jurisdicional efetiva, como MACHADO ${ }^{47}$; e há também os que entendem que, como o $\mathrm{n}^{\circ} 4$ do artigo III365 do TECE foi transposto ao art. $263^{\circ} .4$ do TFUE, haveria de se manter a distinção feita no TECE, de forma que somente seriam abrangidos os atos não legislativos, como WATHELET $^{48}$.

No caso Microban $^{49}$ o Tribunal Geral entendeu pela interpretação mais restritiva, delimitando que o ato regulamentar "deve ser entendido no sentido de que se refere a qualquer ato de alcance geral com exceção dos atos legislativos". Ao pronunciar-se, o Tribunal de Justiça, no caso Inuit Tapiriit Kanatami e outros ${ }^{50}$ e no caso Scuola Elementare Maria Montessori $\mathrm{Srl}^{51}$, confirmou o que já havia sido proferido pelo Tribunal Geral noutros processos, tendo decidido que os atos regulamentares estampados no art. $263^{\circ} .4$ do TFUE não albergam atos legislativos.

Ou seja, no que se refere aos atos legislativos, o particular precisa continuar demonstrando que a afetação lhe é direta e individual, sendo-lhe imposto que preencha o critério Plaumann.

\section{A exceção de ilegalidade no Tribunal de Justiça como solução?}

\footnotetext{
${ }^{47}$ MACHADO, J. Direito da União Europeia. Coimbra: Coimbra Editora, 2010, p. 538.

${ }^{48}$ A saber, o advogado geral Wathelet assim o faz nas conclusões do caso Stichting Woonlinie e o./Comissão, apresentadas em 29-05-2013, processo C-133/12 P. Disponível em < http://curia.europa.eu/juris/document/document.jsf?text=\&docid=137783\&pagelndex=0\&doclang=PT\&mo de=Ist\&dir=\&occ=first \&part=1\&cid=5870615>. Acesso em 18 de junho de 2020.

49 Acórdão Microban International e Microban (Europe)/Comissão, do Tribunal Geral, de 28-10-2011, processo T-262/10. Disponível em $<$ https://eur-lex.europa.eu/legalcontent/PT/TXT/?uri=CELEX:62010TA0262>. Acesso em 18 de junho de 2020.

${ }^{50}$ Acórdão Inuit Tapiriit Kanatami, do Tribunal de Justiça, de 3-10- 2013, processo C-583/11 P, número 112. Disponível em < https://eur-lex.europa.eu/legal-content/PT/TXT/?uri=CELEX\%3A62011CJ0583>. Acesso em 18 de junho de 2020.

51 Acórdão do Tribunal de Justiça (Grande Secção), de 6-11-2018, Scuola Elementare Maria Montessori/Comissão, $\quad$ processo $\quad$ C-622/16 $\quad$ P. $\quad$ Disponível $\quad$ em $<$ http://curia.europa.eu/juris/celex.jsf?celex=62016CJ0622\&lang1=pt\&type=TXT\&ancre=>. Acesso em 18 de junho de 2020.
} 
$\mathrm{O}$ art. 277 do TFUE dispõe que, ainda que se decorra o prazo do art. $263^{\circ} .6$, em se tratando de litígio que ponha em causa ato de alcance geral adotado por uma instituição, um órgão ou um organismo da União, qualquer parte pode recorrer aos meios previstos no $263^{\circ} .2$, para arguir a inaplicabilidade deste ato no Tribunal de Justiça da União Europeia.

Pode-se, num primeiro momento, pensar que a alternativa trazida no art. $277^{\circ}$ é concretizadora da tutela jurisdicional efetiva nos casos em que o particular não satisfaz o critério de legitimidade do recurso de anulação do art. $263^{\circ}$. Isto pois, é dado ao particular, a qualquer tempo, oportunidade de se insurgir perante o Tribunal de Justiça da União Europeia contra a aplicação de atos decorrentes dos atos gerais ilegais.

Apesar da impressão de preenchimento das lacunas do princípio da tutela jurisdicional efetiva mencionado na análise do critério Plaumann, cabe ao estudo verificar se é realmente a exceção de ilegalidade uma solução tão eficaz assim.

A primeira nota que se faz é que a exceção de ilegalidade não é autônoma. A ilegalidade do ato deverá, então, surgir a título incidental, em apoio a um pedido principal que o demandante apresente perante o Tribunal, ou deverá ser alegada como simples meio de defesa num processo em que a parte demandada entenda que o ato é inaplicável ${ }^{52}$. Ou seja, na ausência de um direito de ação principal, o referido artigo não pode ser invocado ${ }^{53}$.

A função desse instrumento é de que os afetados por uma medida baseada em um ato ilegal e de caráter geral da União não se vejam obrigados a serem submetidos aos efeitos ilegais, ainda que impossibilitados de questioná-lo mediante recurso de anulação.

Tem-se então uma decisão que afeta direta e individualmente um particular, e que tem como base jurídica um regulamento (ou outro ato de caráter geral) considerado como ilegal pelo particular. A decisão (a medida individual) é em si mesma irretocável: não contém vícios nas formalidades essenciais, foi adotada pela instituição competente, está conforme ao ato em que se baseia e não foi atingida por desvio de poder. O problema dela é que foi fundada num ato de alcance geral afetado, em tese, pelos vícios trazidos no art. $263^{\circ}$ do TFUE.

Há de existir um nexo de causalidade, de interdependência ou de suficiente conexão, entre o ato de alcance geral (visto como ilegal) e a medida individual de aplicação, já que o

\footnotetext{
${ }^{52}$ MOTA DE CAMPOS, MOTA DE CAMPOS e PINTO PEREIRA., O direito..., op. cit., p. 314.

${ }^{53}$ Ibidem, p. 314.
} 
objeto da exceção de ilegalidade é um ato de alcance geral no qual se baseia o ato impugnado individual. Caso se acate o pedido, é a medida individual que será inaplicada, já que o ato de alcance geral não o pode mais ser ante a expiração do prazo previsto no art. $263^{\circ 54}$.

Além da questão da falta de autonomia da ação e da impossibilidade de questionar ato supostamente nulo por si só, tem-se que, diferentemente do art. $263^{\circ}$, somente poderão servir como base à invalidade os atos de caráter geral, ou seja, tem-se abrangência mais restrita. ${ }^{55}$

O Tribunal mantém o entendimento de que não pode o litigante usar da exceção de ilegalidade quando indubitavelmente lhe teria sido possível, ao abrigo do art. $263^{\circ}$, instar contra o ato um recurso de anulação ${ }^{56}$, (re)afirmando a restrição quando diz que a dedução da exceção de ilegalidade apenas é autorizada na falta de outra via de recurso disponível ${ }^{57}$.

Como se viu, o entendimento de "afetação direta e individual" pelo Tribunal de Justiça nos recursos de anulação é limitadíssimo. Considerando esse fator, não é de se duvidar a ocorrência de situação em que um particular opte por não ingressar com recurso de anulação, ante as diversas e reiteradas decisões negando legitimidade em casos semelhantes, e posteriormente tente utilizar-se da exceção de ilegalidade, mas se veja impedido pelo Tribunal entender que o particular deveria ter atacado o ato no prazo do art. $263^{\circ}$, de forma que a posição do Tribunal não encontra base de apoio e implica grave desproteção dos recorrentes ordinários ${ }^{58}$.

Vê-se então que não é exatamente a melhor solução, de modo que, apesar do prazo extenso, é também instrumento bem limitado, já que se tem as seguintes características: diferentemente do art. $263^{\circ}$, os atos eivados de ilegalidade que podem ser base e mencionados na exceção são somente os atos gerais, sendo a medida mais limitada; os

\footnotetext{
${ }^{54}$ Ibidem, p. 314.

${ }^{55} \mathrm{O}$ Tribunal de Justiça já teve oportunidade de confirmar essa abrangência restritiva do Tratado, e precisou que a finalidade dessa disposição é proteger os interessados contra um regulamento ilegal (ver Acórdão do Tribunal de Justiça da União Europeia de 14 de dezembro de 1962, processos apensos 31/62 e 33/62), destacando-se que pode ser que o ato se revista de caráter geral e abstrato - características de um regulamento, mas sem ter sido designado como regulamento (a exceção feita é se o ato em causa, apesar de não ter caráter geral, tivesse afetado de vícios particularmente graves e evidentes, a ponto de poder ser qualificado de inexistente, conforme acórdão do Tribunal de Justiça de 22.03.2001, Comissão/França, C- 261/99, Colet. I$\left.2537, \mathrm{n}^{\circ} 18\right)$.

${ }^{56}$ Ibidem, p. 823

57 Acórdão de 11.12.2012, Sina Bank, T-15/11, $\mathrm{n}^{\mathrm{o}} \quad$ 44. Disponível em http://curia.europa.eu/juris/liste.jsf?num=T-15/11\&language=EN. Acesso em 18 de junho de 2020.

${ }^{58}$ MOTA DE CAMPOS, MOTA DE CAMPOS e PINTO PEREIRA., $O$ direito..., op. cit., p. 825.
} 
particulares que podem usar são somente os que não puderam intentar recurso de anulação no prazo do art. $263^{\circ}$; é preciso que surja medida de aplicação, de forma que a exceção de ilegalidade é dependente e incidental a uma ação principal, não gozando o particular de direito autônomo a utilizá-la.

Por último, a situação que se chega é esdrúxula, já que o Tribunal de Justiça reconhece que um ato oriundo das instituições europeias é ilegal, mas não o retira do mundo jurídico. Ou seja, podem continuar existindo medidas de aplicação com base nesse ato de caráter geral visto como vicioso, devendo o particular toda vez que afetado por uma delas, usar da exceção de ilegalidade.

\section{E a exceção de inaplicabilidade na ação de indenização?}

É possível aos particulares, albergados pela possibilidade que lhes confere o art. $340^{\circ}$ do TFUE, intentarem ação de indenização, visando reparação de danos, contra a União em razão de atos que lhe causaram prejuízos. O artigo menciona que "a União deve indemnizar, de acordo com os princípios gerais comuns aos direitos dos Estados-Membros, os danos causados pelas Instituições ou pelos seus agentes no exercício de suas funções”.

Ao discorrer sobre o tema, João Mota de Campos, João Luis Mota de Campos e Antonio Pinto Pereira ${ }^{59}$, mencionam que o Tribunal de Justiça tem sublinhado que as condições de efetivação da responsabilidade do Estado por danos causados aos particulares em virtude de violação ao direito da União não devem, em regra, serem diferentes das que regulam a responsabilidade da União em circunstâncias equiparáveis. Ou seja, a proteção que os particulares retiram de direitos vindos do Direito da União não pode variar em função da natureza nacional ou da União da autoridade causadora do prejuízo.

Para regulação da responsabilidade dos Estados-Membros por danos causados aos particulares, tem-se reconhecido que é necessário o preenchimento cumulativo de três requisitos: um comportamento ilegal, um dano real e o nexo de causalidade entre o comportamento e o dano.

Então, quanto aos particulares que não dispõem de legitimidade para atacar os atos da União mediante recurso de anulação, é possível que se vejam amparados, ainda que

\footnotetext{
${ }^{59}$ Ibidem, p. 867.
} 
somente no seio reparatório, mediante ação de indenização ${ }^{60}$. Todavia, para tanto, precisarão apontar a ilegalidade de um ato da União.

Apesar dessa possibilidade, cabe ressaltar que, como também os tem a exceção de ilegalidade, a ação de indenização tem efeitos distintos dos que seriam obtidos por um recurso de anulação. Primeiramente porque só produziria efeitos inter partes ${ }^{61}$, e em segundo lugar porque manteria um ato entendido como ilegal no mundo jurídico.

Como pontuado pelo TPI no sumário do julgamento do caso Jégo-Quere, a ação de indenização não proporciona, em determinados casos, uma solução satisfatória aos interesses dos particulares. Esta ação não pode conduzir a afastar da ordem jurídica comunitária um ato mesmo que, por hipótese, seja considerado ilegal. Tendo como pressuposto a existência de um dano direto causado pela aplicação do ato controvertido, esta ação está sujeita a condições de admissibilidade e de mérito diferentes das que regem o recurso de anulação, e não coloca, portanto, o órgão jurisdicional comunitário em condições de exercer, em toda a sua dimensão, a fiscalização da legalidade que tem por missão efetuar. Em particular, quando uma medida de carácter geral é posta em causa no contexto de uma tal ação, a fiscalização efetuada pelo órgão jurisdicional comunitário não se estende a todos os elementos suscetíveis de afetar a legalidade dessa medida, mas limita-se a sancionar as violações suficientemente caracterizadas de regras de direito que têm por objeto conferir direitos aos particulares.

\section{As limitações do reenvio prejudicial}

\footnotetext{
${ }^{60}$ Vale ressaltar que, conforme Acórdão de 15.07.1963, Proc. ${ }^{\circ}$ 25/62, Colet. 279 (227), Plaumann, à época, propôs conjuntamente o recurso de anulação- cuja admissibilidade foi negada, como visto- e uma ação de indenização. O Tribunal entendeu que a ação de indenização não podia ser aceita, já que o ato não anulado da Comissão não poderia constituir uma falta lesiva, e não poderia o particular, por meio da ação de indenização, ordenar medidas que destruíssem os efeitos jurídicos da decisão não anulados. Ou seja, Plaumann não podia nem intentar recurso de anulação, por ser considerado parte ilegítima, e nem pedir a reparação de danos.

O Tribunal reviu sua posição, e passou a entender a ação de indenização como ação autônoma, dotada de função particular no quadro do sistema das vias contenciosas e subordinada a condições de exercício concebidas em atenção ao seu objeto específico - ver Acórdãos de 28.04.1971, Proc. ${ }^{\circ}$ 7/69, Lütticke III, Colet. , p. 111 (325), no 6 e de 02.07.1974, Proc. ${ }^{\circ} 153 / 73$, Colet. 353 (675).

Apesar disso, ainda resta inadmissível a ação quando a parte buscar exatamente o montante equivalente ais direitos que se encontrava privado em razão de uma decisão/ato que não recorreram por meio de recurso de anulação, e que se tornou definitiva. Tem-se que é vedado à parte intentar ação de indenização destinada, na realidade, à anulação de uma decisão individual tornada definitiva e que teria por efeito, se fosse julgada procedente, anular os efeitos jurídicos de tal decisão. Conforme Acórdão do Tribunal de Justiça de 26.02.1986, Krohn/Comissão, 175/84, Colet., p. 97, números 32 e 33.

${ }^{61}$ MOTA DE CAMPOS, MOTA DE CAMPOS e PINTO PEREIRA., $O$ direito..., op. cit., p. 884.
} 
Como mencionado, por mais de uma vez o Tribunal afirmou categoricamente que a restrita legitimidade para o recurso de anulação não seria limitadora à tutela efetiva dos particulares, justificando tal posição no fato de a ação ser apenas um dos instrumentos judiciais que compõem um sistema completo de vias jurisdicionais. Dentre as outras possibilidades supostamente passíveis de uso pelo particular, cita-se nas decisões o reenvio prejudicial, apontando-o como apto a corrigir a falta de tutela causada por ausência de legitimidade nos recursos de anulação.

O reenvio é citado, posto que, conforme art. $267^{\circ}$ do TFUE, pode ser utilizado pelos particulares perante os tribunais nacionais quando estiver em causa a validade e interpretação dos atos adotados pelas Instituições, órgãos ou organismos da União. O uso desse mecanismo é possibilitado aos particulares a qualquer tempo, em qualquer processo, por via de ação ou via de exceção, de forma bem mais ampla que o recurso de anulação ${ }^{62}$.

Sempre que surgir perante o juiz nacional algo que lhe cause dúvidas suficientes sobre a validade de atos da União, deverá ser feito o reenvio da questão a título prejudicial aos Tribunais da União. As causas de validade que podem ser levantadas no reenvio são as mesmas que fundamentam um recurso de anulação ${ }^{63}$, quais sejam, incompetência, violação dos Tratados ou de qualquer norma jurídica relativa à sua aplicação, violação de formalidades essenciais ou desvio de poder.

A razão de ser do reenvio neste caso se dá porque as jurisdições nacionais não são competentes para pronunciar a invalidade dos atos das Instituições Comunitárias ${ }^{64}$. O juiz nacional, ao se deparar com questionamentos sobre validade pode somente declarar o ato válido, mas nunca inválido ${ }^{65}$, justificando-se a regulamentação na necessidade de coerência e de uniformidade do direito da União - uniformidade esta que é especialmente imperiosa quando está em causa a validade de um ato ${ }^{66}$.

O primeiro inconveniente em alegar que o reenvio é o mecanismo correcional dos efeitos advindos da legitimidade restrita em recurso de anulação se dá na medida em que

\footnotetext{
62 Ibidem, p. 884.

${ }^{63}$ Ibidem, p. 489.

${ }^{64}$ Acórdão do Tribunal de Justiça, de 22 de outubro de 1987, FOTO-Frost, Col. 1987, p. 4199.

${ }^{65}$ Há uma exceção. O Tribunal já aceitou a possibilidade de um órgão jurisdicional nacional basear na invalidade de um ato jurídico da União a imposição de medidas provisórias,. Ver o Acórdão Schul, de 06.12.2005, processo C-461/03. Disponível em < https://eur-lex.europa.eu/legalcontent/PT/TXT/PDF/?uri=CELEX:62003CJ0461\&from=FR>. Acesso em 18 de junho de 2020.

${ }^{66}$ Acórdão do Tribunal de Justiça, de 10.01.2006, IATA e ELFAA, C-344/04, Colet., p. I-403, nº 27 , V.
} 
cabe ao juiz nacional enviar a questão. Ou seja, a não ser nos casos de obrigatoriedade ${ }^{67}$, se o juiz entender que o ato é válido, ele o declara como tal, sem fazer o envio da questão ao Tribunal. O órgão jurisdicional nacional não pode se ver obrigado a aceder a qualquer pedido de reenvio para apreciação da validade de disposições jurídicas da União somente porque a parte suscitou $^{68}$.

O segundo inconveniente diz respeito ao poder do juiz nacional de delimitar o objeto sobre o qual recai sua dúvida. É ao juiz nacional que cabe, então, além de verificar a necessidade de uma decisão prejudicial, verificar a pertinência das questões que coloca ao Tribunal de Justiça ${ }^{69}$. Desta forma, pode ser que o ponto levantado pela parte e o que ela acredita que seja ilegal não coincida com o que o juiz delimita para reenviar ao Tribunal.

Ademais, além de o processo que questiona a legalidade poder ser colocado perante um juiz muito tempo depois da edição do ato, tem-se que a chegada da questão ao Tribunal de Justiça por meio do reenvio pode ser excessivamente morosa, posto que depende dos meios, prazos e organizações de cada jurisdição estatal ${ }^{70}$. Assim, pode ser que um ato inválido fique muito tempo causando efeitos na órbita jurídica de alguém, quando se fosse conferida legitimidade por vias de recurso de anulação, ele teria sido atacado muito antes.

Note-se também que apesar de poderem questionar atos eivados dos mesmos defeitos, os efeitos e objetivos do reenvio e do recurso de anulação são distintos. O acórdão do TJUE sobre a validade não declara, com efeitos para todos, a nulidade do ato da União. O que ocorre é que é declarada a invalidade do ato, com efeitos, em princípio, limitados ao processo pendente no tribunal nacional ${ }^{71}$. Ou seja, a decisão do tribunal não vincula senão o juiz nacional autor do reenvio ${ }^{72}$. O Tribunal de Justiça não declara a ilegalidade do ato, pois ele se tornou inatacável se tiver esgotado o prazo do art. $263^{\circ}$.

\section{Conclusões}

\footnotetext{
${ }^{67} \mathrm{O}$ art. 267, parágrafo $3^{\circ}$, traz que "sempre que uma questão desta natureza seja suscitada em processo pendente perante um órgão jurisdicional nacional cujas decisões não sejam suscetíveis de recurso judicial previsto no direito interno, esse órgão é obrigado a submeter a questão ao tribunal".

${ }^{68}$ MOTA DE CAMPOS, MOTA DE CAMPOS e PINTO PEREIRA., $O$ direito..., op. cit., p. 443.

${ }^{69}$ Ibidem, p. 443.

${ }^{70}$ CORTÉS MARTÍN, Afectación, p.1132.

${ }^{71}$ MOTA DE CAMPOS, MOTA DE CAMPOS e PINTO PEREIRA., $O$ direito..., op. cit., p. 489.

${ }^{72}$ Ibidem, p. 501.

Apesar disso, na prática os outros juízes nacionais ficam dispensados de pedir o reenvio referente a esse tópico, já que já há pronunciamento do Tribunal de Justiça a respeito.
} 
Decorre da jurisprudência que, considerando o fato de a União Europeia ser União de direito e de suas Instituições estarem sujeitas à fiscalização de conformidade dos seus atos com os Tratados, as modalidades processuais (sejam recursos ou ações), devem ser interpretadas e aplicadas de modo que contribuam para realização e garantia da proteção jurisdicional efetiva dos direitos conferidos aos cidadãos ${ }^{73}$.

Com a entrada em vigor do Tratado de Lisboa, restou positivado o que já se dizia: não mais se admitem quaisquer lacunas na tutela jurisdicional de quaisquer direitos advindos da União Europeia, não só dos direitos fundamentais, ${ }^{74}$. Conforme pontuou o advogadogeral Jacobs nas conclusões do caso UPA, “um particular que se considere prejudicado por uma medida que lhe retira um direito ou vantagem ao abrigo do direito da União deve ter acesso a um recurso de tal medida e deve poder beneficiar de tutela jurisdicional total"75.

Ainda que o princípio da eficiência seja muitas vezes relacionado às tutelas dos Estados membros, vale relembrar que ele pontua que as normas processuais não podem tornar impossível ou excessivamente difícil, na prática, o exercício de direitos elencados pelo direito da União. Se os particulares estão protegidos pelo direito da União, essa proteção não pode variar em função da natureza nacional ou da comunitária da autoridade que está na origem do prejuízo $^{76}$, sendo que ainda que a violação venha de ato de Instituição da União, não devem ficar os particulares desamparados e não devem ser afastadas as vertentes do princípio da eficiência.

Por vezes as decisões do TJ apontam uma não lacuna na proteção dos particulares, sob manto de supostamente haver um sistema completo de vias, em que o particular teria meios possíveis a recorrer, geralmente em tribunais nacionais. Quando este argumento é proferido, por vezes esquece-se que uma das vertentes da tutela jurisdicional é que o tribunal apontado como competente seja apto a julgar toda a extensão daquilo que lhe é levado, e que os tribunais nacionais não detêm do poderio de julgar certas questões - dentre elas a invalidade ou nulidade de atos da União - restando aos próprios tribunais da União decidilas.

\footnotetext{
${ }^{73}$ MOTA DE CAMPOS, MOTA DE CAMPOS e PINTO PEREIRA., O direito..., op. cit., p. 103.

${ }^{74}$ FERNANDES, $O$ direito..., op. cit., p.19.

${ }^{75}$ Número 38 das considerações feitas no caso UPA.

${ }^{76}$ MOTA DE CAMPOS, MOTA DE CAMPOS e PINTO PEREIRA., $O$ direito..., op. cit., p. 867.
} 
Além disso, quanto às reiteradas afirmações sobre o sistema ser supostamente completo, foi visto que as alternativas apontadas comumente - o reenvio, a exceção de ilegalidade ou a ação de indenização - ainda que de competência dos tribunais da União, não constituem alternativas eficazes e sequer têm o mesmo objetivo. No que toca especificamente ao reenvio, apontado como principal alternativa, destacou-se que, a despeito de diversas decisões do Tribunal de Justiça sobre o tema, em nenhuma delas há resposta efetiva no sentido de o reenvio ser uma faculdade ao juiz nacional, e não direito do demandante ${ }^{77}$.

Há então que se reconhecer que os particulares, em sua grande maioria, não detêm legitimidade para questionar os atos oriundos das Instituições da União Europeia, e também não lhes é oferecida, nem em jurisdição nacional e nem em jurisdição da União, alternativa com objetivo semelhante ao do recurso de anulação, sendo-lhes denegada justiça e denotando um verdadeiro vão em sua proteção jurisdicional. O resultado indesejável que se chega com a jurisprudência atual é de que os particulares se encontram menos protegidos de atos na atualidade do que antes da existência da União, o que precisa ser mudado.

Uma das teses levantadas pelos particulares é de que dever-lhes-ia ser conferida legitimidade em recursos de anulação, ao passo que não gozam doutro meio judicial, e que isto deveria ser levado em consideração para admissão ou não do recurso. A solução não parece ser das mais adequadas, já que fato de o particular ter ou não ter meios mediante a jurisdição nacional não é apontado como condicionante à legitimidade no TFUE. Ainda, aceitar tal hipótese seria dar ao Tribunal uma tarefa à qual ele não tem meios e nem competência para fazer em sede de recurso de anulação, além de autorizar disparidade de tratamento entre particulares afetados da mesma maneira pelo ato, a depender do Estado de origem deles $^{78}$.

Comentou-se que inexistem de vias alternativas, e acrescentou-se que, além disso, a via do recurso de anulação é a que melhor se presta a resolver as questões de invalidade. Os outros métodos - que como se viu, não solucionam as demandas dos particulares - têm objetivos distintos e restritos.

\footnotetext{
${ }^{77}$ CORTÉS MARTÍN., Afectación..., op. cit., p.1146.

${ }^{78}$ COOKE, Locus..., op. cit.. p 7.
} 
Mostrou-se que é preferível ao sistema, por questões inclusive de segurança jurídica, que se identifique de forma clara e rápida as regras que devem ser consideradas como inválidas, descartando-as do ordenamento tão pronto quanto possível, a fim de evitar novas situações de ilegalidade ${ }^{79}$. É então no seio do próprio recurso de anulação que, tanto a legitimidade de pessoas quanto a nulidade de atos, precisam ser resolvidas.

O objetivo de ampliar a tutela jurisdicional efetiva poderia ocorrer por simples alteração jurisprudencial. O Tratado traz a expressão afetado individualmente, e o entendimento do que isso significa em termos de legitimidade foi firmado de forma restritiva em 1963, e desde então se mantém. Diferentemente dos Tribunais Europeus, a tendência nas jurisdições nacionais tem sido justamente de aumentar a legitimidade dos particulares para levarem suas pretensões ao Estado - o que se justifica inclusive pelo caráter publicista que tem vigorado pelos estudiosos nas ciências processuais nas últimas décadas ${ }^{80}$ - fato que foi também pontuado nas referidas conclusões do advogado-geral Jacobs ${ }^{81}$.

À luz da jurisprudência do Tribunal Europeu dos Direitos do Homem, parece não coexistir o atual critério Plaumann com a tutela jurisdicional efetiva ${ }^{82}$. É negado o acesso à justiça aos particulares que não são destinatários do ato e que não são afetados de forma análoga ao destinatário: aos que se encontram nessas situações não são dadas possibilidades reais e eficazes de demonstrarem suas colocações sobre a nulidade do ato, sobrando-lhes apenas a alternativa de aguardar que algum legitimado o faça e, em caso contrário, conviver com o ato.

Ressalte-se que não há razões no Tratado que justifiquem a exigência de afetação individual ser entendida como afetação distinta de todos os demais e análoga ao destinatário, podendo muito bem ser tal exigência afastada.

Citou-se duas fórmulas para o entendimento de afetação individual trazidas, respectivamente pelo advogado-geral Jacobs no caso UPA e pelo TPI no caso Jégo-Quére, quais sejam, respectivamente: "uma medida comunitária diz individualmente respeito a uma pessoa quando, em razão das circunstâncias particulares desta, a medida afeta ou é suscetível de afetar negativa e substancialmente seus interesses", e a "disposição de caráter geral que

\footnotetext{
${ }^{79}$ CORTÉS MARTÍN, Afectación..., op. cit., p.1147.

${ }^{80}$ MITIDIERO, D. Colaboração no processo civil: pressupostos sociais, lógicos e éticos. 3. ed. rev., atual. e ampl. de acordo com o novo código de processo civil. São Paulo: Editora Revista dos Tribunais, 2015, p. 104. ${ }^{81}$ COOKE, Locus..., op. cit., p. 8.

${ }^{82}$ CORTÉS MARTÍN, Afectación..., op. cit., pp.1160-1161.
} 
disser diretamente respeito a uma pessoa lhe dirá individualmente respeito se afetar, de forma certa e atual, a sua situação jurídica, restringindo os seus direitos ou impondo-lhe obrigações".

Rui Moura Ramos, ao mencionar que a interpretação atual constitui entrave significativo para o acesso dos particulares à justiça comunitária, sugere, de maneira muito próxima à sugestão do advogado-geral Jacobs, que dever-se-ia interpretar a afetação individual não em função de uma afetação radicalmente distinta de todos os outros, mas sim “em função de algo que provoca um prejuízo grave, certo e substancial na ordem jurídica do particular" $" 83$.

Por todo o exposto, tem-se que a efetividade dos mecanismos de fiscalização jurisdicional é diretamente dependente das possibilidades reais de acesso pelos afetados, subsistindo todos os vieses do princípio da tutela jurisdicional efetiva ainda que se fale em competências da União, cabendo somente ao Tribunal de Justiça decidir que é o momento de alterar sua jurisprudência e reverter o cenário.

Apenas merece nota final o fato de que, após o Tratado de Lisboa, o Tribunal teve oportunidade de ampliar o acesso aos tribunais europeus pelos particulares sem necessidade de alteração do conceito tão clamado de afetação individual. Poderia tê-lo feito (mas não o fez) quando, chamado a se pronunciar sobre a nova hipótese introduzida no art. $263^{\circ}$ - qual seja, a possibilidade de atacar os atos regulamentares que afetassem diretamente um particular e que não demandasse medidas de execução- tivesse decidido em sentido não tão restritivo do que são atos regulamentares. Se assim o fizesse, atos regulamentares de todas as formas, e que fossem independentes de medidas de execução, poderiam ser atacados quando afetassem diretamente um particular, ampliando a legitimidade para recurso de anulação, sem, no entanto, ceder e alterar a jurisprudência sedimentada de afetação individual.

\section{REFERÊNCIAS}

\section{Doutrina:}

CAMPOS, João Mota de, CAMPOS, João Luis Mota de, PEREIRA, Antonio Pinto, Manual de Direito Europeu, $7^{\text {a }}$ ed, Coimbra, Coimbra Editora, 2014.

\footnotetext{
${ }^{83}$ MOURA RAMOS, O Acesso..., op. cit., p. 440.
} 
CAMPOS, João Mota de, CAMPOS, João Luis Mota de, PEREIRA, Antonio Pinto, $O$ direito processual da União Europeia: contencioso comunitário, $2^{\mathrm{a}}$ ed., Lisboa, Fundação Calouste Gulbernkian, 2014.

CHLOUPEK, Vojtech, "How to Challenge a Community Measure: Recent Case Law on Standing of Individuals in Actions for Annulment", Common L. Rev., 6 (9), (2004).

COOKE, John D, “Locus Standi of Private Parties under Article 173 (4)”, Irish J. European L., 6 (1), 1997, pp.4-23.

CORTÉS MARTÍN, José M, “Afectación individual (230.4 CE): ¿um obstáculo infranqueable para la admisibilidad del recurso de anulación de los particulares?”, Revista de Derecho Comunitario Europeo, 2003, pp. 1119-1173.

FERNANDES, Filipa, $O$ direito fundamental à ação e as suas implicações no contencioso da União Europeia pós-Tratado de Lisboa: Por um «Mecanismo Europeu de Resgate» dos Direitos dos Particulares, Cascais, Editora Principia, 2015.

MACHADO, Jónatas, Direito da União Europeia, Coimbra, Coimbra Editora, 2010.

MARQUES, Francisco Paes, "O Conceito de Acto Legislativo no Direito da União Europeia”, In Estudos de homenagem ao Prof. Doutor Jorge Miranda, vol. 5, Coimbra, Coimbra Editora, 2012, p. 117-140.

MESQUITA, Maria José Rangel de, Introdução ao Contencioso da União Europeia, Coimbra, Editora Almeidina, 2015.

MITIDERO, Daniel, Colaboração no processo civil: pressupostos sociais, lógicos e éticos, 3. ed. São Paulo, Editora Revista dos Tribunais, 2015.

MOURA RAMOS, Rui Manuel, "Locus Standi dos particulares no contencioso de anulação em direito comunitário", In Estudos de Direito da União Europeia, $2^{\mathrm{a}}$ ed., Coimbra, Editor GESTLEGAL, 2019, pp 403-434.

MOURA RAMOS, Rui Manuel, "O acesso dos particulares aos Tribunais Europeus”, In Estudos de Direito da União Europeia, 2ª ed., Coimbra, Editor GESTLEGAL, 2019, pp 435-441.

MOURA RAMOS, Rui Manuel, "O Tribunal de Justiça e o Acesso dos Particulares à Jurisdição da União após as alterações decorrentes do Tratado de Lisboa”, In Estudos de Direito da União Europeia, $2^{\text {a }}$ ed., Coimbra, Editor GESTLEGAL, 2019, pp. 291320. 
MOURA RAMOS, Rui Manuel, "O Tratado de Nice e a Reforma do Sistema Jurisdicional Comunitário", In Estudos de Direito da União Europeia, $1^{\mathrm{a}}$ ed., Coimbra, Coimbra Editora, 2013, pp. 113-141.

MOURA RAMOS, Rui Manuel, “The Adaptation of the Portuguese Constitutional Order to Community Law”, In Estudos de Direito da União Europeia, $1^{\mathrm{a}}$ ed., Coimbra, Coimbra Editora, 2013, pp. 53-63.

MOURA RAMOS, Rui Manuel. "Tribunal de Justiça das Comunidades Europeias”, In Estudos de Direito da União Europeia, $1^{\text {a }}$ ed., Coimbra, Coimbra Editora, 2013, pp. 337-343.

PAIS, Sofia Oliveira, “Assimetrias no Contencioso da União Europeia depois de Lisboa e a Sensação de Dèjà Vu", In Estudos de homenagem ao Prof. Doutor Jorge Miranda, vol. 5, Coimbra, Coimbra Editora, 2012. pp. 559-574.

PROENÇA, Carlos, "Proteção jurisdicional efetiva na União Europeia: evolução e perspectivas (ou expectativas) futuras", Debater a Europa, n. 15, julho/dezembro 2016.

RAVO, Linda Maria, "The role of the Principle of Effective Judicial Protection in the EU and its Impact on National Jurisdictions", Sources of Law and Legal Protection, (Triestine Lecture; 1), EUT Edizioni Università di Trieste, 2012, pp. 101-125.

USHER, John A, "Direct and individual concern - an effective remedy or a conventional solution?", European Law Review 2003, 28(5), 575-600.

\section{Acórdãos, despachos e conclusões de advogado geral, em ordem cronológica:}

Acórdão do Tribunal de Justiça, de 14 de dezembro de 1962, Empresa Milchwerke Heinz Wöhrmann \& Sohn KG e Empresa Alfons Lütticke GmbH contra Comissão da Comunidade Económica Europeia, Processos apensos 31/62 e 33/62.

Acórdão do Tribunal de Justiça, de 15 de Julho de 1963, Plaumann \& Co. contra Comissão da Comunidade Económica Europeia, Processo 25-62.

Acórdão do Tribunal de Justiça, de 16 de Dezembro de 1976, Rewe-Zentralfinanz eG e Rewe-Zentral AG contra Landwirtschaftskammer für das Saarland, Processo 33-76.

Acórdão do Tribunal de Justiça, de 23 de abril de 1986, os Verdes, Proc. 294/83, Partido Ecologista "Les Verts" contra Parlamento Europeu, Processo 294/83. 
Acórdão do Tribunal de Justiça, de 22 de outubro de 1987, Foto-Frost contra Hauptzollamt Lübeck-Ost, Processo 314/85.

Acórdão do Tribunal de Justiça, de 27 de Setembro de 1988, Parlamento Europeu contra Conselho das Comunidades Europeias, Processo 302/87.

Acordão do Tribunal de Justiça, de 16 de maio de 1991, Extramet Industrie SA contra Conselho das Comunidades Europeias, Processo 358/89.

Acórdão do Tribunal de Justiça, de 18 de Maio de 1994, Codorniu SA vs. Conselho da União Europeia, Processo C-309/89.

Despacho do Tribunal de Primeira Instância, de 9 de Agosto de 1995, Greenpeace e o./Comissão, Processo T-585/93.

Acórdão do Tribunal de Primeira Instância, de 13 de Dezembro de 1995, Vereniging van Exporteurs in Levende Varken e Nederlandse Bond van Waaghouders van Levend Vee contra Comissão, Processos apensos T-481/93 e T-484/93.

Acórdão do Tribunal de Justiça, de 14 de Dezembro de 1995, Peterbroeck, Van Campenhout \& Cie SCS contra Estado Belga, Processo C-312/93.

Despacho do Tribunal de Primeira Instância, de 23 de novembro de 1999, Unión de Pequeños Agricultores (UPA) contra Conselho da União Europeia, Processo 173/98.

Acórdão do Tribunal de Justiça, de 22 de março de 2001, Comissão das Comunidades Europeias contra República Francesa, Processo C- 261/99.

Acórdão do Tribunal de Primeira Instância, 27 de setembro de 2000, BP Chemicals Ltd contra Comissão das Comunidades Europeias, Processo T-184/97.

Conclusões do Advogado-Geral F. G. Jacobs, de 21 de março de 2002, em Unión de Pequeños Agricultores (UPA) contra Conselho da União Europeia, Processo C-50/00 Recurso de decisão do TPI- Processo no TPI 173/98.

Acórdão do Tribunal de Primeira Instância (Primeira Secção Alargada), de 3 de Maio de 2002. - Jégo-Quéré \& Cie SA contra Comissão das Comunidades Europeias, Processo T$177 / 01$.

Acórdão do Tribunal de Justiça, de 25 de Julho de 2002, Unión de Pequeños Agricultores contra Conselho da União Europeia, Processo C-50/00 P- - Recurso de decisão do TPIProcesso no TPI 173/98. 
Acórdão do Tribunal de Justiça (Sexta Secção), de 01 de abril de 2004, Comissão das Comunidades Europeias contra Jégo-Quéré \& Cie AS, Processo C-263/02 P.

Acórdão do Tribunal de Justiça (Grande Secção), de 10 de Janeiro de 2006, The Queen, a pedido de International Air Transport Association e European Low Fares Airline Association contra Department for Transport., Processo C-344/04.

Acórdão do Tribunal Geral, de 25 de outubro de 2011, Microban International Ltd e Microban (Europe) Ltd contra Comissão Europeia, Processo T-262/10.

Acórdão do Tribunal de Justiça, de 06 de novembro de 2012, de 6 de novembro de 2012, Europese Gemeenschap contra Otis NV, Processo C-199/11.

Acórdão do Tribunal Geral, de 11 de dezembro de 2012, Sina Bank contra Conselho da União Europeia, Processo T-15/11.

Conclusões do advogado-geral Melchior Wathelet, apresentadas em 29 de maio de 2013, no caso Stichting Woonlinie e o./Comissão, Processo C-133/12.

Acórdão do Tribunal de Justiça (Grande Secção), de 3 de outubro de 2013, Inuit Tapiriit Kanatami e o. contra Parlamento Europeu e Conselho da União Europeia, Processo C$583 / 11$.

Acórdão do Tribunal de Justiça (Grande Secção), de 6 de novembro de 2018, Scuola Elementare Maria Montessori Srl contra Comissão Europeia, Comissão Europeia contra Scuola Elementare Maria Montessori Srl e Comissão Europeia contra Pietro Ferracci, Processo C-622/16. 